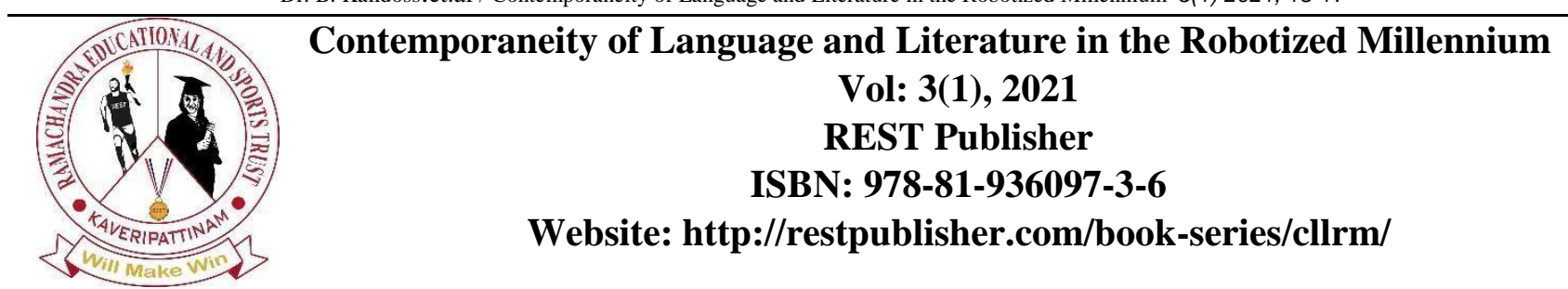

\title{
Gender Identity in Kishwar Naheed's Select Poems
}

\author{
Dr. B. Kalidoss \\ Arul Anandar College, Karumathrur, Madurai, Tamil Nadu, India. \\ Email: dossjishnu@gmail.com
}

\begin{abstract}
Woman's inferior status in society is a result of differences in the upbringing of man and woman, not of natural differences. Male domination is not inherent or natural but conditioned at every stage of development in the human history. Over the course of centuries men have established their superiority by degrading women. As men are feared by the thought of losing their power over the female race, they belittle women in order to make superior themselves and validate their own masculinity. They are treated as other. It has become a tradition and culture in the patriarchal society. Dishware Named in her poems raises her rebellious voice against this kind of treatment and asserts that human beings in general need to think beyond the position their sex holds in society. This paper is an attempt to provide how women are identified as a daughter, mother and a wife and their struggle under the banner of culture and religion. The poems taken for discussion are: I am not that Woman, The grass is really like me, We Sinful Women, My Nation, Listen to My Entreaty, Fulfillment of Borrowed Joys and Ants Consume the Elephant.
\end{abstract}

Keywords: domination, disparage, patriarchal, belittling.

Gender identity is the major concern in the literature of feminism particularly in the eastern countries like Pakistan, Indi, and Bangladesh. It is not natural but culturally constructed. Women have been unjustly denied from achieving full equality in many societies around the world. Though they share half of the population they are facing discrimination and degradation in many areas of life. The oppression of women especially in the third world has reached awful levels. Woman is being treated as a mother, daughter, sister or wife, the society always desires that she should be amenable, timid and submissive. In a family she normally allowed to play the role either a devoted wife or a devoted mother. She is not respected as an independent being. Women were not supposed to raise voices for their rights, protest against injustice or question the already existing beliefs, customs, rituals, traditions and superstitions. They have to be merely subjected to the patriarchal system in a male-dominated world, where she has very little scope to give voice to her concerns. Naheed has always been at the forefront as fast as the women's issues are concerned in her society. This paper is an attempt on how Kishwar Naheed has revolted against these problems in her poems. For the purpose of this article a handful of poems of Kishwar Naheed have been analyzed with reference to gender identity. The poems taken up for this purpose are: I am not that Woman, The grass is really like me, We Sinful Women, My Nation, Listen to My Entreaty, Fulfillment of Borrowed Joys and Ants Consume the Elephant. Kishwar Naheed was born in Uttar Pradesh, India in 1940 and migrated to Lahore, Pakistan after Partition. Naheed's writing career, which began approximately in the late 1960s, is based on themes that critique the relationship between women and patriarchal states and societies. Her work is based on the experience of the subcontinent feminine - its issues, challenges and concerns. She although was individually targeted by Zia-ul-Haq's military regime, continued to write during 1977-1988. Naheed is widely popular in Pakistan and the global community for her women-positive poetry. Her concern is not for an individual but is for the whole class, whose history has been swept under the layers of social amnesia regulated by a strict patriarchal politico-religious code. The main concern of Naheed's poems is to retrieve the history of women. In one of her poems 'The Grass is Really like me', she draws an interesting and innovative analogy between grass and herself. This poem is the outcry against the age old patriarchal attitude regulated by political and religious code. She uses the metaphor to represent women. The poet associates herself with the grass because she feels that the condition of women and of the grass is the same. "The grass is also like me it has to unfurl underfoot to fulfil itself" The efforts of the gardener to "mow" down the raised grass' is compared to the grim politics of patriarchal society manifested in many ways to bring down the women. However, these efforts turn futile as no one can curb, "... neither the earth's nor woman's desire to manifest life dies." When the poet says 'me', she does not talk only about herself, but she talks of the entire womenfolk. The poet's message is very clear. Whatever may be the tactics adopted by patriarchy to suppress a woman, she will rise again and again unperturbed in her spirits. The mood becomes visible in the very first lines, "....As soon as it can raise its head the lawnmower obsessed with flattening it into velvet, mows it down again." While the actual lawnmowers cut down the grass to the ground level, the metaphorical lawnmowers, i.e. the men strangulate the freedom of women by keeping them submissive. The aggressive assertion and opposition to repressive customs and traditions continue in her another well known poem, I am not that woman wherein she asserts, I am not that woman selling you socks and shoes! 
She refers to a model or actress who allows her to be dressed in lucrative clothing in order to promote a commercial product. She is not that woman to be projected as a mere symbol of sexual object. Sexualized images may aggravate violence against women and girls, sexual harassment, and anti-women attitudes among men. Sexualized images can pave way further for victimization of women. Men keep women indoors, restrict their movements and forbid them from leaving the house. Walking freely outside is considered immodest and disgraceful especially in the regions of the east. Named is making it clear that the main purpose that women are locked indoors is not to safeguard them but because women are considered inferior and a burden. She wants to convey that a woman can become a powerful woman if she does not have the bonds of marriage, motherhood, and maintainer of tradition. Named addresses the hypocritical nature in which men are free to go wherever they please without any care or question while women are literally locked behind stone in an attempt to silence their mind. This is explicitly seen in this line."I am the one you hid In your walls of stone, while you roamed Free as the breeze, not knowing my voice cannot be smothered by stones." She is rather, the woman who has been suppressed by the rigid constraints of custom and irrational attitude of tradition. As Virginia Woolf writes in her A Room of One's Own: "imaginatively she is of the highest importance: practically she is completely insignificant. She ... pervades poetry from cover to cover. She is all but absent from history." The poet raises her voice saying that men forget to know that women are talented and their thoughts and voice cannot be controlled by the so-called traditional stones. "I am the one you crushed With the weight of custom and tradition Not knowing That light cannot be hidden in darkness." No matter how men try to replace her flowers of hope and aspiration with thorns and chains of contempt they will not succeed in silencing her mind, because she is not that woman. You picked flowers and planted thorns and embers not knowing that chains cannot smother my fragrance". Named uses symbols to referring to her character as the flowers that were in her lap, and the restrictions and harsh words addressed to her as embers and chains. There is positive approach that she cannot be abused. Woman is sometimes complicit in her 'Otherness' because her dependence is comfortable, and she can derive satisfaction in that role. But she must break the chain. In the eastern culture daughters and women are considered to be a burden because her parents are expected to give the groom a very large dowry, many times this ends up in lakhs of rupees worth of furniture, jewels and clothes. Thus the parents trade off their daughters in the name of marriage. "I am the one you married off / To get rid of a burden". The female persona refuses to be a half-naked woman selling products on a poster. She refuses to disrespect herself and her body, refuses to objectify her body for others to see and receive pleasure. Woman is not a sexual object, a reproductive body, while man, as subject can do anything and everything within the range of his ambition and imagination. Her stance should be seen as a strong reaction to the masculinity consumerism. "I am the commodity you traded in, my chastity, my motherhood, my loyalty. Now it is time for me to flower free." Naheed continues to rebel through her another poem We Sinful Women. This poem is referred to as a women's anthem among Pakistani feminists. It is a strong declaration of the independence of women who vehemently opposed to the societal and cultural norms still exist in Pakistan. Women are treated as objects and properties, and exploited due to man-made law of power and men's justice. The agrarian imagery 'harvests of our bodies' fits well with the tendency to describe female body in terms of vegetative imagery."It is we sinful women while those who sell the harvests of our bodies become exalted become distinguished become the just princes of the material world." Named in her poem My Nation, Listen to My Entreaty exposes how men society imposes restriction on women in the name of religion and how the same makes use of to marginalize them and suppress their voice. This poem not only voices for the marginalized women but also challenging the dominant hegemonic structure like religion operating in the society. "Our nation accepts everything and every person This nation accepts tyrants It accepted lackeys, accepted imposters". Wally asserts that "two particular types of malecentric society - private and open male-controlled society". Pakistan society has accepted these two and implemented on women. If the suppressed women claim their rights they will be sent out of the sphere of Islam and treated like a criminal. It is described in these lines in the poem."Yes, but if any woman emerges with a banner in hand instantly they will speak instantly delete her from the sphere of Islam, from every reward of life. O my nation!'Women are sexually exploited by men. Men consider women's body as a sexual object. Whenever they see 'in the every shape of women they see lust' they are driven by lust. Ahmad argues that, "When states, societies, and families fail to safeguard the rights of a person or a group, literature stands sentinel to protect those rights braising voice against injustices and atrocities...it generated conflicts, with tradition and to some extent, religion, as interpreted by men and expressed in fundamentalist Islam" (Ahmad, 1990. P.7) Fulfillment of Borrowed Joys claims that patriarchy defined the position and identity of women. They have to be imprisoned in kitchen to prepare food and taking care of children and giving birth to children like a machine according to man-made rules in the patriarchal society. They are, in fact, in charge of production and reproduction in their family. These women are degraded, marginalized and silenced in such patriarchal society."After the setting of the sun every color loses its existence when I come to the kitchen to take care of everyday things then all the colors of my being sink." Her poem Ants Consume the Elephant speaks about the women who have no rights in their marriage. They are forced to marry a man who is no choice of their own. They have no right to choose their husbands. Forced marriages are quiet common in Pakistani male chauvinist society. "On whom should I write a poem now that girl who cannot marry of her own accord and those who point fingers, her own blood, are petitioners of justice?" 


\section{Conclusion}

Naheed's determined fight for women's rights is evident through her scholarly contributions. A woman should be aware, self controlled, strong willed, self reliant and rational, having faith in the inner strength of womanhood. A meaningful change can be brought only from within by being free in the deeper psychic sense. It must be noted that Naheed's poetry is not limited to the women of Pakistan by rather speaks for the entire community particularly the East. In sum, it is very crystal clear in her poems that change can only occur when vague notions of inferiority, superiority, and equality are abandoned.

\section{Works Cited}

1. Ahmad, Rukhsana, ed. and Trans. We Sinful Women: Contemporary Urdu Feminist Poetry. The Women's Press, 1991.

2. Beauvoir, Simone de. The Second Sex. Vintage Books, 1989.

3. Walby, S. (1990). Theorizing Patriarchy. Blackwell Publishers Ltd.1990. 